\title{
The Notions of the Human Person and Human Dignity in Aquinas and Wojtyla
}

Jove Jim S. Aguas

\section{Introduction}

$A$ $t$ the center of the various transformations and advancements in modern society is man. It is man by whom and for whom these transformations and advancements are made. But one negative factor accompanying these transformations is the violence or the degradation of the human person and his dignity, more alarming is the violence committed by man against his fellow man. Today, there is so much violence in the world, everyday we hear about killings, kidnappings, rapes, abortion, terrorist attacks, hunger, wars and many other acts of violence. It is ironic that, while the human person is the very victim of this violence, it is also the human person who is the perpetrator of such violence, man is simultaneously the victim and the culprit. Man indeed is a paradox, for while he is bestowed with dignity and good nature, he is also capable of doing evil and inflicting harm against others. This violent tendency happens because man fails to acknowledge the very dignity of his nature which is rooted in his fundamental relation with God and extended to his fellow human beings. Man is by nature good, but he is also capable of doing evil things. The Catholic Church through its teachings and writings have always emphasized the value of the person, while at the same time acknowledging the fact that he is as much capable of degrading himself. The Pastoral Constitution of the Church in the Modern World, "Gaudium et Spes" acknowledges the many divergent and contradicting opinions of man about himself, one of which "exalts man as the absolute measure of all things and debases himself to the point of despair. The result is doubt and anxiety."

But let us focus on the brighter side of man, his dignity as a person. The "Gaudium et Spes," quoting the Scriptures, stresses that man was created "in the image of God" and that he is capable of knowing and loving his Creator. He was appointed by God to be the master of all earthly creatures; was made little less than the angels and crowned him with glory and honor. ${ }^{2}$ Indeed man is in a privileged position among God's creatures in the world for he alone is gifted with spirit, with intellect and will. ${ }^{3} \mathrm{He}$ is the only being in this world

\footnotetext{
${ }^{1}$ Gaudium et Spes, Part I Chapter I. \#12.

${ }^{2}$ Ibid.

${ }^{3}$ Jove Jim S. Aguas, "Affirming the Human Person and Human Dignity: A Rereading of Aquinas." in UNITAS, 75:4 (December 2002), 560.
} 
whom we can call a person because of his inner spiritual life. John Paul II writing as Karol Wojtyla said:

A person differs from a thing in structure and in the degree of perfection. To the structure of the person belongs an "inner" in which we find the elements of spiritual life and it is this that compels us to acknowledge the spiritual nature of the human soul and the peculiar perfectibility of the human person. ${ }^{4}$

In contemporary philosophy especially in existentialism, we always refer to the human person as a concrete subject and a fellow man, stressing the fact that the human person is not just an abstract and logically defined concept, but more significantly a concretely existing subject who co-exist with his fellow human persons and ordained for interpersonal relationship.

At the outset, let us stress that the human person, both as a subject and a fellow man enjoys an inalienable dignity. ${ }^{5}$ This dignity is based on the very fact that man is a being created by God in His own image and likeness. The book of Genesis tells us that God created man his own image and likeness, male and female he created him; man depends on God for his existence and activities. This basic dignity comes directly from God's creative act not from any action on the part of man.

While human person and human dignity have become the favorite concepts and bywords in contemporary discussions, like in philosophy, anthropology, politics, religion and even in discussions about social and political issues, there is a lack of proper understanding of what really these concepts and realities are. Sometimes, these realities I would say are often used to justify certain interests or philosophies, like a government program or policy that would promote the dignity of the human person, when in fact it does not. So to attract and gain acceptance of their programs or policies, some people would use the terms "human person" and "human dignity," without fully understanding the meanings and the implications of these realities. So there is a need to put on the discussion table these concepts and realities once again to allow us to gain better insights about them.

\footnotetext{
${ }^{4}$ Karol Wojtyla, Love and Responsibility, trans. by H.T. Willets (San Francisco: Ignatius Press, 1993), 121.

5 The term dignity was taken from the Latin term dignus which means worthy of esteem and honor, due a certain respect, of weighty importance. In ordinary discourse, dignity is used only in reference to human persons. The early Greeks, held that not all human beings have worth and dignity, most humans are by nature slavish and suitable only to be slaves. Most men do not have natures worthy of freedom and nature proper to free men, hence they never used the term dignity for all human beings but only to a few. While other traditions have limited dignity to some kinds of men, the Judeo-Christian tradition made human dignity a concept of universal application. See Michael Novak. "The Judeo-Christian Foundation of Human Dignity, Personal Liberty and the Concept of the Person," $<$ http://www.action.org/publicat/m_and_m/1998_Oct/novak.html $>$.
} 


\section{HUMAN PERSON AND HUMAN DIGNITY}

This paper then is written for two reasons. First, given the alarming violence in our society there is a need to reaffirm the value and dignity of the person. The notion of the human person and his inherent dignity transcends all limits and boundaries pertaining to the differences in beliefs, convictions, worldviews, cultures and ideologies. By going back to the very essence of the person and his dignity, we will realize the transcendence of the human person. Second reason is to gain valuable insights from the philosophies of the human person and dignity which can serve as our moral guide in our relation with one another.

And for our purposes we will turn to the thoughts of the St. Thomas Aquinas, who although belongs to the middle ages, his ideas are still relevant today if we can also revitalize his philosophy and allow him to have a dialogue with other philosophers about contemporary philosophical issues. ${ }^{6}$ Another staunch defender of the human person and human dignity was John Paul II, who, before becoming the Supreme Pontiff and writing as Karol Wojtyla developed his own understanding of the human person and defended in his writings the dignity of the human person.

While St. Thomas did not experience the same horrors and violence inflicted against the human person, Wojtyla was both a witness to and a victim of these horrors. Aquinas' reason for writing on the human person is less personal, it is more "objective;" Wojtyla's reasons are personal and more "subjective," and he drew inspiration from his own personal experiences. Hence, the theme of the human person and his dignity, is one idea or subject that runs through the whole of Wojtyla's work like an ever recurring theme. Many variations are played on this theme as his thought progresses but it always remains beneath or within them as the enduring subject. ${ }^{7}$ When he was elected as Pope and adapted the name John Paul II, he continued writing on this subject, his encyclicals, addresses, and sermons always touched on this subject. But in order to show the essence of the person and his dignity, he turned to the thoughts of St. Thomas and re-appropriated Aquinas' ontology of the person.

\section{Aquinas and Wojtyla on Person}

\section{The Essence of Man}

In order to find out why man has a dignity of and by himself, we must examine the principle of whatness of man, his essence. In this sense, we need to go back to metaphysics, for it is metaphysics that provides us the ontological and ultimate ground of the essence of man and it is through metaphysics that

6 While others may have some resentment towards Thomism branding it as "medieval" we can still revitalize it by new hermeneutic that would allow new understanding of Thomistic principles. Aristotle and Plato lived much older than St. Thomas and addressed ancient issues, but we never brand their philosophies as too "ancient."

7 Peter Simpson, On Karol Wojtyla (Belmont CA: Wadsworth/Thomson Learning, 2001), 7 . 
we gain a better insight about the essence and reality of the human person. ${ }^{8} \mathrm{~A}$ real philosophy must have some grounding on metaphysics, for a real philosophy must touch upon being. This is not to say that Aristotelian or Thomistic metaphysics is the only metaphysics, but we cannot deny the fact that Aristotle provided us with a comprehensive metaphysics and this which taken up by St. Thomas.

Essence and existence, (esse) are the intrinsic constitutive principles of a real being. Essence is basically a potential principle which requires actuation by existence or esse. Essence is that which makes a thing what it is, it is the principle of determination and limitation. Essence is individuated in the reality but because it is universal in the mind, it is sometimes confused with other concepts which are universal. But unlike other concepts, it a real principle of the reality. Furthermore, essence does not only tell us what a thing is but what it can become or what it ought to be. Essence has a concrete content and has natural tendencies, it is not an inert but a dynamic principle so that it is the principle of operation. ${ }^{9}$

Many simply ignore or deny that man has an essence because they understand essence simply as an inert and not a dynamic principle and also not as a potential but an actual principle. Such an understanding of essence is generally either a logical understanding of essence, conceived as an abstract, formal and strictly universal concept like other concepts, or an epistemological understanding of essence, imagined as something unknowable beneath the attributes of a thing. ${ }^{10}$

The universal human essence explains the simple fact that one may say that human individuals $\mathrm{A}$ and $\mathrm{B}$ are both human or man despite all the differences between them. In other words, the universal human essence enables us to express in reality the logically minimal and yet metaphysically fundamental identity of two concrete existing men insofar as they share in one and the same human species, that is, humanity. ${ }^{11}$

Understood as a potential principle, human essence does not contradict the diversity of customs and cultures. Man's capacity for language, for example, explains rather than contradicts the diversity of languages because this capacity of his is not for one particular language. The capacity to worship the divine does not contradict the diversity of religious beliefs rather it explains it. Furthermore the universal human essence does not contradict the particularity of the individual and his free self-creation but rather it renders both possible. ${ }^{12}$ It is noteworthy in this context that there is no such a thing as

\footnotetext{
8 Aguas, 562.

9 Cf. Etienne Gilson. Being and Some Philosophers (Toronto: Pontifical Institute of Medieval Studies, 1952), 115-121.

10 Chang Wook. "The Ultimate Foundation of Human Dignity in St. Thomas Aquinas," in Acta of the Fourth International Conference of the Asian Association of Catholic Philosophers. Humanity in the 21st Century: Towards A New Vision. Seoul (The Research Institute of Korea, CUK, 2000), 95.

${ }^{11}$ Ibid.

12 Ibid.
} 


\section{HUMAN PERSON AND HUMAN DIGNITY}

the completely and exclusively, that is, absolutely, particular, all essential characteristics, that is characteristics that proceeds from the human essence, of an individual are universal. The particular is in fact an individualized universal.

Agere sequitur esse. What or how a being is, so it acts. Action follows being and operation follows essence. Essence is the principle of operation and is known through its operations. In the case of man the highest operation is intellection and St. Thomas showed that intellection is a spiritual operation and, therefore, the human soul is a spiritual substance. St. Thomas' reasoning proceeds more precisely from the immateriality or spirituality of the object of intellection to that of the human soul. From the immateriality or spirituality of the object and immateriality of the operation we know the immateriality or spirituality of the intellect and immateriality or spirituality of the subjectman. ${ }^{13}$

The immateriality or spirituality of man signifies man's actuality, which in turn, signifies beingness and perfection. Consequently, the spirituality of the human soul signifies its actuality, and with it, its beingness and perfection. The spirituality of the human essence is founded on the human soul's subsistence. The human soul's subsistence means that it is spiritual, that it exists and acts of and by itself, independently of matter or the body. This shows the degree of beingness, actuality and perfection it possesses.

St. Thomas teaches, however, that the human soul is the substantial form of the body and is, at the same time, its subsisting form. ${ }^{14}$ This selfsubsistence of the human soul is the basis for his teachings that it is not educed from matter as that it does not come from the souls of the parents and is immediately created by God and as such it is incorruptible and everlasting. ${ }^{15}$

Human essence understood as potentiality is the ground for the selfactualization of man. ${ }^{16}$ Rather than a hindrance for man's self- expression and freedom, it provides the ontological ground by which all these human determinations are possible. For how can man make possible his selfdeterminations, if in the very first instance he is not a subject with his distinct essence?

"As essence is the principle of potentiality, determination and limitation, the universal human essence makes possible the human individual's self-creation as an actualization and realization of the human essence as his own essence."17 And consequently since essence is the principle of what is and also what ought to be, the specifically human essence of the human individual does not only render his self-creation a free and responsible one but also

13 Cf. S. Th., I. q. 79, a.3, a.5; q. 84, a.6; q 85, a.1.

14 Cf. S. Th., I, q. 76, a. 1.

${ }^{15}$ Cf. S. Th., I, q. 85 , a. 6 ; q. 90 , a. 2, a.3.

16 Some existentialists, particularly Sartre criticized the conception of human essence as hindrance to man's freedom and self-creation. According to Sartre man creates his own essence, there is not such thing as divine creator who created for man his (man) own essence. Man exists first and gradually creates his own essence. However, this position is inadequate, for it that cannot answer the problem of the essence of an existing subject who must have some basis from which he could create something.

${ }^{17}$ Ibid., 96. 
bestows upon the individual the responsibility of conforming his self-creation to his nature and to rationality, which is his specific difference.

\section{Nature of the Human Person}

St. Thomas, following the ideas of those philosophers before him like Boethius assigned the name person to individual beings with rational nature. He wrote:

So a special name is given among all other substances to individual beings having a rational nature, and this name is 'person'. Thus in this definition of person, the tern 'individual substance' is used to refer to a singular being in the category of substance; 'rational nature' is added to mean the singular being among rational substances. ${ }^{18}$

Of course, the human person is not just a metaphysical concept. On the contrary, the human person is the concrete, existing human individual. The human person denotes the presence of a living human individual. But the metaphysical concept of person denotes the essence of person, by virtue of which person is person. We have to note that the metaphysical concept of person is not merely one concept among many different types of universal concepts in the mind but it is a concept which stands for the metaphysical reality of the person in the real world. As a concept, the concept of person is universal and thus is bound to be abstract. Therefore, the concept of person expresses only in an abstract and universal manner what the individual person is.

As is well known, St. Thomas followed Boethius definition of person. The person according to Boethius is an individual substance of rational nature. Substance is a being which is complete in itself so that it exists independently. It is that which endures in change and is subject of properties and operations. The Boethian definition of person denotes the ontological structure or essence of a person. It is therefore an essential determination rather than an existential determination. However, the categories and principles of the realist and existentialist metaphysics of St. Thomas, brings out the existential aspect of the human person.

The person is a spiritual being, a being having rational, intellective soul and essence. Hence the person and the spiritual being mean ontologically the same. The degree and kind of personality of a person correspond to the spirituality of a spiritual being. Hence the human person and the human

18 S. Th., I, q. 29, a. 1, c. (..by adding "individual" we eliminate the notion of a reality that can be assumed by another. Thus the human nature in Christ is not a person because it is assumed by a greater being, namely the Word of God. S. Th., I, q., 29, a. 1, c ad. 2.) 


\section{6}

HUMAN PERSON AND HUMAN DIGNITY

spiritual being also mean ontologically one and the same thing. And in the hierarchy of beings, man is the lowest person, the lowest spiritual being. ${ }^{19}$

The Boethian definition of person is simple but profound in meaning. Although there have been many definitions or explanations about the essence of the person, such definition, although too abstract, has validity even in our days. St. Thomas accepted this definition. But there are others, however, who reject it for a variety of reasons, arguing that man is a mystery which defies any definition, that person is indefinable and, finally, that the metaphysical definition or concept of person is abstract, and is, therefore, inappropriate for denoting the concrete human individual. Indeed man is a mystery, a paradox in himself, but to say that he defies definition in the sense that we cannot say anything sensible about his essence is absurd. ${ }^{20} \mathrm{We}$ acknowledge, the limitation of a metaphysical definition, since man is not just a concept and is not simply a metaphysical reality, but a concrete human individual, then a metaphysical definition is inadequate. That is why we have to show and define man, the human person in concrete and human condition. This is not to say that we have to abandon completely metaphysics, for after all, man is a being.

\section{The Problematic Condition of the Human Person}

It is general knowledge that Wojtyla endured tragic experiences during his early life, experiences that molded his personality, his thinking and his thoughts. He lost his mother at an early age, and his brother when he was ten years old, and he endured the different upheavals that crushed Eastern Europe during the twentieth century. During the middle years of the twentieth century, his native country, Poland, like other Eastern European countries was crushed by two brutal tyrannies, one after another: Nazism and Communism. As a young man living with his father, Wojtyla not only observed but experienced the horrors of these regimes. He too, was a victim and had his shares of pains and sufferings, first during the Nazi occupation and later during the Communist regime in Poland. Many of his friends and associates particularly the Jews, perished during the onslaught of Nazism. In these brutal and horrible events, Wojtyla saw how man can be both the agent of goodness and evil. In both regimes, the capacity of man to sink to the level of the beast or rise to that of an angel, are equally manifested. ${ }^{21}$

Nazism and Communism were built on ideologies with negative views on man, ideologies that regard the other human being, the individual who is different from them, either in religious belief, nationality or political persuasion, as less human, or not human at all. Those who profess and

${ }^{19}$ Chang, 122.

${ }^{20}$ As a mystery we would rather, live, act and relate with the human person, appreciate his existence rather define his essence. But since our concern is to investigate the essence of man, then we are bound to pose a definition. For one requirement of a sound philosophy is the articulation of meaning and therefore any philosophy of the human person must be able to come up with a definition of the person, albeit imperfect. See Aguas, 567.

${ }^{21}$ Ibid., 8. 
believe in a different ideology or religion were subjected to inhuman treatment. Wojtyla throughout his childhood and until he became the Supreme Pontiff was in the midst of these ideologies first as a victim and then as a staunch crusader against them. In his short autobiography, written as John Paul II, he remarked about how his tragic experiences with these two systems influenced his deep concern for the dignity of the human person. He wrote:

The two totalitarian systems which tragically marked our century - Nazism on the one hand, marked by the horrors of the war and the concentration camps, and communism on the other, with its regime of oppression and terror - I came to know, so to speak, from within. And so it is easy to understand my deep concern for the dignity of every human person and the need to respect human rights, beginning with the right to life. This concern was shaped in the first two years of my priesthood and has grown stronger with time. It is also easy to understand my concern for the family and young people. These concerns are all interwoven; they developed precisely as are result of those tragic experiences. ${ }^{22}$

But it was not only the ideologies of Nazism and Communism that needed to be confronted. There was the emerging consumerism, the kind of materialism that pervaded in the West. The consumerist societies focused so much on the quantitative development of man's condition but paid little attention to the human person himself. ${ }^{23}$

Wojtyla was not only attuned with the political and social upheavals that were happening during his time, he was also very much aware of the impact of these controversies and struggles on our appreciation and understanding of the human individual. He observed:

It is a time of great controversy about the human being, controversy about the very meaning of human existence, and thus about the nature and significance of the human being. This is not the first time that Christian philosophy has been faced with a materialistic interpretation, but it is the first time that such an interpretation has had so many means at its disposal and has expressed itself in so many currents. This aptly describes the situation in Poland today with respect to the whole political reality that has arisen out of Marxism, out

\footnotetext{
22 John Paul II, Gift and Mystery (New York: Doubleday , 1996), 66-67.

${ }^{23}$ Simpson, 8.
} 


\section{HUMAN PERSON AND HUMAN DIGNITY}

of dialectical materialism, and strives to win minds over to this ideology. ${ }^{24}$

The Communist, Nazi and other similar ideologies and consumerist orientations together with their tragedies and horrors, caused untold sufferings of on the human person. All these consumed the thoughts of Karol Wojtyla. He fully realized that in order to uplift and promote human dignity, these ideologies, together with their brutal regimes, as well as the emerging consumerist and materialist orientations must be opposed. If there was a way to oppose them, it must be a philosophy of the human person which regards every man, regardless of race, religious beliefs or political orientation as a human being with dignity. When he was elected to the Papacy, he became more vigilant and focused his energies and teachings on how to combat these ideologies and orientations, for the protection of the human person and his dignity.

No wonder then that his treatment of the issue of the human person was not so much on the epistemological aspect, or on the theoretical side, but it was more on the ethical, the practical, specifically the anthropological. He focused more to work in favor of an enrichment of the realistic image of the person, and on the need to authenticate the foundations of such a philosophy of person.

\section{The Problem of the Subjectivity}

The problem about the condition of the human person is not only caused by political ideologies and social and economic orientations. In the area of philosophy, anthropology and ethics, there is more specific problem within the issue of the human person itself, and that is the issue about the subjectivity of the human person. Wojtyla explained that the problem of the subjectivity of the human person lies at the very foundation of human praxis and that philosophy has an important role in the proper understanding of this issue. He stressed:

In addition, the problem of the subjectivity of the person-particularly in relation to human communityimposes itself today as one of the central ideological issues that lie at the very basis of human praxis, morality (and thus also ethics), culture, civilization, and politics. Philosophy comes into play here in its essential function: philosophy as an expression of basic understandings and ultimate justifications. The need for such understandings and justifications always accompanies humankind in its sojourn on earth, but this need becomes especially

${ }^{24}$ Karol Wojtyla, "Person, Subject and Community," in Person and Community: Selected Essays. translated by Theresa Sandok, OSM (New York: Peter Lang, 1993), 220. 
intense in certain moments of history, namely, in moments of great crisis and confrontation. 25

Wojtyla further observed that the problem of the subjectivity of man is the subject of many-sided interests, and he acknowledged that he shared the same interest. He stressed that indeed the problem of the subjectivity of the human being is a problem of paramount philosophical importance today and divergent tendencies with their differing cognitive assumptions and orientations have given the problem diametrically opposed form and meaning. ${ }^{26}$ He wrote: "The problem of the subjectivity of man seems to be today the focal point of a variety of concerns. . ." The heart of the issue is precisely found in this point: "Today, more than ever before, we feel the need, and also see a greater possibility, of objectifying the problem of the subjectivity of the human person." 27

Wojtyla traced the root of this problem from the long history of Western thought. He noted that while the old antinomies that arose in the area of the theory of knowledge and formed a seemingly inviolable demarcation line between basic orientations in philosophy seemed to have been set aside and ignored in contemporary thought. The oppositions between subjectivism and objectivism, as well as that between idealism and realism turned to be discouraging discussions on human subjectivity. He explained: "the antinomy of subjectivism vs. objectivism, along with the underlying antinomy of idealism vs. realism, created conditions that discouraged dealing with human subjectivity - for fear that this would lead inevitably to subjectivism." 28 This created according to Wojtyla an unfavorable climate for the study of human subjectivity, because of the fear that such endeavor would only lead to subjectivism. This fear is justified by the idealistic "overtones" of the analysis based on "pure consciousness." 29 This issue on pure consciousness, further strengthened the line of demarcation in philosophy and the opposition between the objective and subjective view of the human being.

Thus, there emerged two contrasting conceptions of man: the objective which is anchored on ontology and the subjective which is based on the idealistic analysis based on pure consciousness. Consequently, in the field of philosophy there became a fix line of demarcation and opposition between the objective or objectivistic conception man-which is based on the ontological conception of man as being-and the subjective or the subjectivistic conception of man, which seemed to cut man off entirely from the ontological reality of the subject. ${ }^{30}$

\footnotetext{
25 Wojtyla, "Person, Subject and Community," 220.

${ }^{26}$ Ibid., 219.

${ }^{27}$ Karol Wojtyla. "Subjectivity and the Irreducible in the Human Being," in Person and Community: Selected Essays, trans. by Theresa Sandok, OSM (New York: Peter Lang, 1993), 209.

${ }^{28}$ Ibid.

29 This is actually Wojtyla's reaction against the idealistic tendency of the phenomenology of Husserl.

${ }^{30}$ Ibid.
} 


\section{HUMAN PERSON AND HUMAN DIGNITY}

But Wojtyla was quick to point out that such demarcation is breaking down and he ascribed such break down to the method itself of phenomenology. By going back to human experience, we are liberated from pure consciousness and we are introduced to the whole concreteness of the existence of man, that is, to the reality of the conscious subject.

\section{Person}

Wojtyla's Reinterpretation of Aquinas' Notion of

The response of Wojtyla to the problem of the human person is a different kind of orientation, a kind of attitude that is focused on the value and dignity of the human person. In his short autobiography, Wojtyla acknowledged the influence of his formation within the horizon of personalism which, for him, allows one to appreciate the uniqueness of the human person. He wrote: "My formation within the cultural horizon of personalism also gave me a deeper awareness of how each individual is a unique person. ${ }^{31} \mathrm{He}$ tried to avoid the pitfalls of any theoretical conception of the human person and clarified that, "personalism is not primarily a theory of the person or a theoretical science of the person." He stressed: "Its meaning is largely practical and ethical: it is concerned with the person as a subject and an object of activity, as a subject of rights, etc." ${ }^{2}$ For his personalism, he turned to St. Thomas and Max Scheler. ${ }^{33}$

The Thomistic theological personalism is primarily based on the concept of the person as it is applied to the Trinity and Incarnation. By analogy, the concept of person as applied to the Trinity can also be applied to man. Following the thoughts of St. Thomas on this matter, Wojtyla wrote:

. . . whatever is a true perfection in the created world must be found in the highest degree in God, and so the person, too, which signifies the highest perfection in the world of creatures, must be realized in an incomparably more perfect degree in God. ${ }^{34}$

He further asserted the Thomistic position that in the created world, the person is the highest perfection: the person is perfectissimum ens. 35

St. Thomas, as we have already discussed, followed the Boethian definition of person: persona est rationalis naturae individua substantia. From this

\footnotetext{
${ }^{31}$ John Paul II, Gift and Mytery, 94.

32 Karol Wojtyla, "Thomistic Personalism," in Person and Community: Selected Essays, trans. by Theresa Sandok, OSM (New York: Peter Lang, 1993), 166.

33 Although this personalism of Wojtyla was largely based on the theological personalism of St. Thomas, he also drew certain insights from the phenomenology of Max Scheler. His personalism is a good blend, a harmonious synthesis of Thomism and Schelerian phenomenology.

${ }^{34}$ Ibid.

${ }^{35}$ Ibid., 167.
} 


\section{J. AGUAS 51}

view, a rational nature does not possess its own subsistence as a nature, it subsists in a person. The person then is a subsistent subject of existence and action. In the created world, the human person is objectively the most perfect being and such perfection is the result of the rational and thus spiritual nature which subsist in the person. Reason and with its complement freedom, are the two properties concretized in the person. ${ }^{36}$ The person therefore is "always a rational and free concrete being, capable of all those activities that reason and freedom alone make possible." 37

It is the rational soul that gives man his spiritual capacities or faculties of intelligence and will and makes him a person. But man is not just composed of a soul, man is composed of both the spiritual and corporeal: the spirit and the body. St. Thomas explained this union of the body and spirit through the hylomorphic analysis: byle, which means matter and morphe which means form. The soul is the form, while the body is the matter. And like any other hylomorphic creature, there is a substantial union between matter and form or the body and the soul. Following the philosophy of Aristotle, the soul, in the case of man, the spirit, is the substantial form of the body, it animates the body, it makes it move and act. It is the principle of life and activity of the human being. According the Wojtyla, this fact is of, "basic importance for understanding the whole uniqueness of the human person, as well as for explaining the whole structure of the human person..$^{38}$

The body and spirit have their respective powers or capacities. The soul operates through the mediation of the faculties and the two highest powers of the spirit are intelligence through reason or intellect and rational volition through the will. It is through reason and will that the spirituality of man is actualized and through which man realizes himself. ${ }^{39}$ Based on the activities of reason and will, the whole psychological and moral personality takes shape..$^{40}$ As the substantial form of the body, aside from the spiritual powers, the soul has powers or faculties that are intrinsically dependent on matter or the body, these are the sensory faculties: the cognitive faculties which are the senses, and the appetitive faculties, the emotions or feelings. These faculties since they belong to the concrete human being are also found in the person and therefore contribute to the shaping of the psychological and moral personality. So following St. Thomas, Wojtyla asserted that all the faculties of the human soul work to perfect the human being, thereby contributing to the development of the human person. ${ }^{41}$

Indeed, it this complex constitution of the human person as composed of the material and spiritual aspects that makes him unique from all other entities in the world. Together with the other entities, he can be considered as

\footnotetext{
${ }^{36}$ Ibid.

${ }^{37}$ Ibid.

38 Ibid., 168.

${ }^{39} \mathrm{Ibid}$. See a similar discussion on this topic in Mary Shivanandan, Crossing the Threshold of Love (Washington: The Catholic University of America Press, 1999), 47-48.

40 Wojtyla, "Thomistic Personalism," 168.

${ }^{41}$ Ibid., 168-169.
} 


\section{HUMAN PERSON AND HUMAN DIGNITY}

an object; but because of his nature, the human person is also a subject. As a subject, he is an entity that exists and acts in a certain way, he exists as an object, that is, an objective somebody. Wojtyla clarified: "As an object, man is 'somebody' and this sets him apart from every other entity in the visible world, which as an object is always only "something." 42

It is therefore not enough to define man just as an individual of the species homo, Wojtyla insisted that the term person has been coined to signify that man cannot be entirely contained with the concept of individual member of the species, because there is more to him, there is a particular richness and perfection in the manner of his being that can only be brought out by the use of the term "person." 43 The most obvious and basic reason for this as we have mentioned earlier is the ability to reason, which cannot be said of the other entities in the world. Man is a rational being and this differentiates him from the whole world of objective entities, this is man's distinctive character as a person. The person is distinguished from all other entities even from the most advanced animal because of his specific inner self, an inner life that is characteristic only of person. While the other entities may have life, like the plants and animals and have desire and cognition like the animals; it is only man, whose cognition and desire is stamped with a spiritual character, which is fundamental in the formation of a genuine interior or inner life.

Because of his spiritual life, which is the basis of his rationality and because of his inner being and interior life, man is a person and is therefore distinct from all other entities. While this characteristic sets him apart from all these entities, it is also such spiritual life that allows him to be involved and related to the world of objective entities. Wojtyla stressed:

A person is an objective entity, which as a definite subject has the closest contacts with the whole (external) world and is most intimately involved with it, precisely because of his inwardness, its interior life. ${ }^{44}$

The contact and relation of the person with everything in the external world is not purely based on the physical nor the sensual. As a distinctly defined subject, he establishes contact with all other entities through his inner self. While it is true that his contact with the outside world starts with the physical or the natural and the sensitive or sensual because he has a body which is his means of communicating with the outside world, the impressions and messages presented to him are received and processed by his internal faculties. He does not react to them in a purely spontaneous or mechanical manner, but according to his spiritual and rational nature. And his nature includes the power of reason and self-determination which are based on his intellect and will.

\footnotetext{
${ }^{42}$ Karol Wojtyla, Love and Responsibility, 21.

${ }^{43}$ Ibid., 22.

${ }^{44}$ Ibid., 23.
} 


\section{Basic Dimensions of the Human Person and Human Dignity}

Contemporary philosophers, including many Thomists, remind us of the importance of the concept of person. But what does it mean concretely to be a human person? The human person has two basic dimensions, first his personality or personhood and second, his sociality.

\section{Human Spirituality and Sociality}

The human person's personhood is rooted in his spirituality. From the thoughts of St. Thomas we find that the spirituality of man constitutes the very core of the human person and from this core springs his intentions, thoughts, motives and feelings. Hence while it could be said that man shares the vegetative and sentient faculties and operations with the plants and animals, such faculties and operations cannot be reduced to the level of the plants and animals, for such operations are grounded in the spiritual and rational nature of man. And because of this spiritual dimension, the human person should not be reduced to the level of things or objects or animals. Karol Wojtyla, who was influenced by Thomistic principles believed that man's subjectivity signifies the person's "irreducibility" to the level of things and animals, the human person is not just some sample of nature. He occupies a special place in the order of created beings. He stressed it clearly when he wrote:

The person is not an "individualized humaness;" it actually consists rather in the mode of individual being that pertains to mankind alone. This mode of being stems from the fact that the peculiar type of being proper to mankind is personal. 45

However, although this spiritual aspect of man is the very core of his being, the human person is not just a pure spiritual subject, he is a concrete subject, incarnating his inner self through his body. The human person is a concrete I, existing and acting. In other words, man is not just a being specifically defined but as a "concrete I," a concrete subject living himself." 46 In other words the human person is a concrete individual.

In the field of concrete experience, the human person is given both as a specific subject and a concrete "I" that is nonrecurrent and unique. Therefore we have to understand him both as a subject and a concrete "I" that

45 Karol Wojtya. The Acting Person, trans. of Osoba i Czyn by Andrzej Potocki, established in collaboration with Cardinal Wojtyla by Anna-Teresa Tymieniecka for publication in the Reidel Book Series Annalecta Husserliana. (Dordrecht, Holland; Boston, USA; London, England: D. Reidel Pub. Co., 1979), 83.

${ }^{46}$ Karol Wojtyla. 'Subjectivity and the Irreducible in Man,' in Analecta Husserliana. (1978), 111. 


\section{HUMAN PERSON AND HUMAN DIGNITY}

is both existing and acting. As a unique and concrete subject, he stamps his existence and every utterance, action and attitude with uniqueness. The human person as a unique and unrepeatable subject possesses and dominates himself. He alone decides for himself and determines his own existence and action, he alone thinks, wills and loves for himself.

A person is self-subsistent: he is self-oriented and self-purposed. This means that he is an end in himself; a being with an absolute value. A person has a dignity of his own which is not bestowed on him by another. His incommunicable, inviolable and absolute rights are not subject to negotiation. A person is radically free, in the sense that he has the right and freedom of responsible self-creation and self-fulfillment.

The human person possesses himself, he is aware of himself, governs himself and masters himself. His spiritual essence enables him to be actively a self; he becomes self-manifesting and self-communicative, self-sharing and selfgiving. And, finally, the human person is self-transcending. He transcends himself in the sense that he goes beyond all what is relative and temporal and can relate with the absolute and eternal. ${ }^{47}$ The human person's capacity for intense self-possession expresses itself in a conscious, free and responsible selfcreation. Self-possession does not mean being locked up in oneself but to be self-giving. By virtue of the spirituality of his essence, the human person is a being open to the world. 48

The second dimension of the human person is his sociality. The human person is a social individual. The human person is a member of the society only as a being, infinitely transcending the society. Definitely, the scope of the human personhood is wider than that of his sociality. The human personhood is ontologically prior to the human social dimension. Therefore, a society which is worthy to be called human, is a society of persons, founded on the ontological principle of common human spiritual essence and not on contract alone. ${ }^{49}$ So, while it is true that society emerged from contract or consent among rational individuals, it must be emphasized that those who entered into such contract are human persons who has the inherent capacity for interrelation and communication.

The human person is a member of the society first by his nature and secondarily by contract. And therefore the human social dimension must be based on the human personhood. Only such a human social dimension which rooted on his personhood, can provide all the means which are necessary for mans self-fulfillment as a person. Hence while it is true that man is by nature a social being, he is first and foremost a person.

Man's personhood and sociality are his two basic dimensions and although they interpenetrate and also overlap each other, one is not reducible to the other. The latter is founded on the former. The human sociality is an

\footnotetext{
47 See Aguas, 569.

48 Ibid.

${ }^{49}$ John Locke pointed out in his Social Contract Theory that society is the result of a free contract among men, for mutual protection of rights and security. The same thought was expressed by Thomas Hobbes in his Leviathan. Although they differ as to the nature of the man.
} 
aspect of the human person's self-manifestation and self-sharing and also that of his openness to the world and to others. Man is not created by, the society but the society is created by man. Man is clearly not indebted to the society for his humanity and personhood. But man can fulfill himself to the full extent only as a member of the human society.

\section{Personhood: Immediate Cause of Human Dignity}

Man has dignity because he is a person. According to St. Thomas, the "person," refers to that which is most perfect in the whole of nature, namely, to that which subsists in rational nature. Now since God has all perfection and we attribute every perfection to him, then it is just proper to use the word person when we speak of him. However, we can also use the term person to other rational substances in a lower sense. 50

Human dignity is rooted in man's personhood, the dignity of man is based on his spiritual essence. As we have already mentioned, the immateriality or spirituality of man signifies man's actuality. This in turn, signifies beingness and perfection. Hence, the spirituality of the human soul signifies its actuality, and with it, its beingness and perfection. The human dignity is, therefore, founded on the spirituality of the human essence as the principle of actuality. The human dignity is the expression of the high degree of beingness, actuality and perfection that the human essence possesses. In final analysis, the human dignity is then founded on, and the expression of, the beingness, actuality and perfection of man as a spiritual being. But such essence and beingness and perfection, do not proceed from man himself, but from a Divine Being who is the source of perfection and being.

The dignity of man of man then, though grounded in his essence as a person, acquires a greater significance because it came from a divine source. Man's personal essence is a participation of the divine personal essence hence his dignity is a participation of the divine dignity. ${ }^{51}$ St. Thomas explains this participation of the divine dignity through his notion of man as a being created in the image and likeness of God.

\section{Man as Imago Defi: The Ultimate Foundation of Human Dignity}

In what sense is man created in the image and likeness of God? In what sense do we participate in the dignity of the divine? St. Thomas provides us with the philosophical ground and explanation for these assertions. $\mathrm{He}$ wrote:

. . . all creatures are images of the first agent, namely, God, because the first agent produces its like. Now, an

\footnotetext{
50 S. Th., I, q. 29, a. 3, c.

${ }^{51}$ Aguas, 571.
} 


\section{HUMAN PERSON AND HUMAN DIGNITY}

image's perfection is found in reproducing the original through resemblance, this is why an image is made. And so all things are made in order to acquire as their last end a divine likeness. ${ }^{52}$

While all creatures bear some resemblance to God, only in a rational creature do we find a resemblance to God in the manner of an image; other things resemble him in the manner of a trace. ${ }^{53}$ Hence God exists in things in two ways: first as an operative cause, and in this way he exists in everything that he creates and second in a special manner in rational creatures that are actually knowing and loving him or are disposed to do so. ${ }^{54}$ St. Thomas further wrote:

Man is made in God's image, and since this implies, so Damascene tells us, that he is intelligent and free to judge and master of himself, so then, now that we have agreed that God is the exemplar cause of things and that they issue from his power through his will, we go on to look at this image, that is to say at man as the source of actions which are his own and fall under his responsibility and control. 55

It is clear then that man is made after God's image. The likeness to God in terms of image means that his being in God's image signifies his capacity for understanding, and for making free decisions in master of self." While in terms of likeness means that "he is in his likeness refers to the likeness of divine virtue, in so far as it can be in man." 56

\section{Man as Sui Juris}

The person because of his reason and free will is a sui juris., he is his own master and therefore cannot be determined by the external impressions and messages from the external world. In addition to this his personality is alteri incommunicabilis, it cannot be transferred to somebody else. In other words, the human person is not just a master of himself, he is at the same time a unique and unrepeatable entity. Although this characteristic can also be said of other entities, man's inalienability is intrinsic to the person's inner life, because his free will and power of self-determination. ${ }^{57}$ Nobody can decide for us, nobody can want for us, no one can substitute his will for ours. It may happen that sometimes we do the things that others want us to do, but we do

\footnotetext{
52 Summa Contra Gentiles I, 19.

53 S. Th., I, q. 93, a. 6, c.

${ }^{54}$ Cf. $S$. Th., I, q. 8, a. 3.

55 S. Th., 1a, 2ae, Prologue.

56 S. Th., I. Q. 93, a. 9, c.

${ }^{57}$ Ibid., 24.
} 


\section{J. AGUAS 57}

this either because we also will it or we do it against our will, in short, externally we may be compelled to do certain actions, but the will cannot be compelled to desire something which is against it.

For Wojtyla, the assertion that the human being is a person holds a very profound theoretical significance; for regardless of the differences in worldviews, everyone agrees with this assertion. That the human being is a person speaks of the natural greatness of this being, it asserts that the human being as a person holds a position superior to the whole of nature and stands above everything in the visible world. ${ }^{58}$ The human person as we have constantly stressed is a rational and free being, with his intellect and freedom as essential and irrevocable properties of his essence. Here lies according to Wojtyla the whole natural basis of the dignity of the human person. ${ }^{59}$ Wojtyla further wrote:

To acknowledge the dignity of the human being means to place people higher than anything derived from them in the visible world. All the human works and products crystallized in civilizations and cultures are only a means employed by people in the pursuit of their own proper end. Human beings do not live for the sake of technology, civilization or even culture; they live by means of these things, always preserving their own purpose. ${ }^{60}$

\section{Final Remarks}

It is not only St. Thomas and Wojtyla who stressed the dignity of the human person, many other writers from different traditions and ideologies have championed the dignity of the human person. The German philosopher, Immanuel Kant, in the light of his categorical imperative, stressed the value of the human person as an end in itself. Man, and that is every rational being, for him exists as an end in himself. Kant stressed: "Act so that you treat humanity whether in your own person or in that of another, always as an end and never as a means only." 61

The encyclical "Pacem in Terris" stressed that any human society, if it is to be well-ordered and productive, must lay down as a foundation this principle, namely, that every human being is a person, that is, his nature is endowed with intelligence and free will. Indeed, precisely because he is a person he has rights and obligations flowing directly and simultaneously from

\footnotetext{
58 Karol Wojtyla, "The Dignity of the Human Person" in Person and Community: Selected Essays, trans. by Theresa Sandok, OSM (New York: Peter Lang, 1993), 178.

${ }^{59}$ Ibid.

${ }^{60}$ Ibid., 178-179.

${ }^{61}$ Cf. Immanuel Kant, Foundations of the Metaphysics of Morals, trans by L.W.Beck (New York: Library of Liberal Arts, 1959), 428-29.
} 


\section{HUMAN PERSON AND HUMAN DIGNITY}

his very nature. ${ }^{62}$ Every person has basic rights and responsibilities that flow from his human dignity and that belong to every human person, regardless of any social or political structures. These rights include those things that make life truly human. Corresponding to our rights are duties and responsibilities to respect the rights of others and to work for the common good of all. And as these rights and obligations are universal and inviolable, so they cannot in any way be surrendered. ${ }^{63}$

Human persons therefore must never be treated as a means to whatever end. All human persons are ends to be served by the social and economic institutions that make up the society. Human persons are not means to be exploited for more narrowly defined political, social and economic goals. Societies must uphold the dignity of persons and must treat them not as tools or instruments but as the very end they have to serve. ${ }^{64}$

Only where man is considered as person, can there be not only an absolute foundation for the absolute meaning of human dignity and the inviolability of human rights but also an ontologically founded unity and equality of members of the society as sharing the same human essence. What is needed is a genuinely human social order, which promotes not only such material values like social, economic and political but also the spiritual, moral, religious, intellectual and cultural values, all of which the human person needs for his self-fulfillment. The all-embracing and ultimate end of the society is the self-realization of man as a person, a realization that is anchored in human dignity.

Christianity stressed that every human person is loved by the Creator, made in His image and likeness and destined for eternal friendship and communion. ${ }^{65}$ Each human being must be accorded the due respect because he participates in the dignity of God, the Creator. Human personhood must be respected with a reverence that is religious. When we deal with each other, we should do so with the sense of awe that arises in the presence of something holy and sacred. ${ }^{66}$ Today, there is a growing awareness of the sublime dignity of the human person, who stand above all things and whose rights and duties are universal and inviolable. Every human person then must have ready access to all that is necessary for living a genuinely human life. ${ }^{67}$

The notions of human person and human dignity transcend ideological, cultural and political differences. Regardless of color, religion, creed and belief, we are all human persons and we all enjoy the same dignity. Such essence and dignity of the human person are shared and must be enjoyed

\footnotetext{
62 Encyclical Letter "Pacem in Terris" Pope John XXIII, April 11, 1963. \#9.

63 "Pacen in Terris" \#9.

${ }^{64}$ Jove Jim S. Aguas, "Promoting Human Dignity in a Culture of Violence" in Philosophy, Culture and Traditions, 3 (2005), 67.

${ }^{65}$ Novak, op cit.

${ }^{66}$ See "Economic Justice for All," Pastoral Letter on Catholic Social Teaching and the US Economy. US Catholic Bishops, 1986. \#28.

67 "Gaudium et Spes," Pastoral Constitution on the Church in the Modern World. Promulgated by Pope Paul VI, December 7, 1965. \#26.
} 
by all peoples, they are what transcend the limits posed by the differences in worldviews, beliefs, convictions and ideologies. Violence arises when man's shared essence and dignity are overshadowed and undermined by their differences.

\section{College of Accountancy, University of Santo Tomas, Philippines}

\section{References}

"Economic Justice for All" Pastoral Letter on Catholic Social Teaching and the US Economy (US Catholic Bishops, 1986).

Aguas, Jove Jim S., "Affirming the Human Person and Human Dignity: A Rereading of Aquinas." in UNITAS, 75:4 (December 2002). , "Promoting Human Dignity in a Culture of Violence" in Pbilosopby, Culture and Traditions, 3 (2005).

Aquinas, Thomas, Summa Contra Gentiles. , Summa Theologic.

Gilson, Etienne, Being and Some Philosophers (Toronto: Pontifical Institute of Medieval Studies, 1952).

John Paul II, Gift and Mystery (New York: Doubleday , 1996).

Kant, Immanuel, Foundations of the Metaphysics of Morals, trans. by L.W.Beck (New York: Library of Liberal Arts, 1959).

Novak, Michael, "The Judeo-Christian Foundation of Human Dignity, Personal Liberty and the Concept of the Person," $<$ http://www.action.org/publicat/m_and_m/1998_Oct/ novak.html>.

Pope John XXIII, "Pacem in Terris," (April 11, 1963).

Pope Paul IV, The Pastoral Constitution of the Church in the Modern WorldGaudium et Spes (1965).

Shivanandan, Mary, Crossing the Threshold of Love (Washington: The Catholic University of America Press, 1999).

Simpson, Peter, On Karol Wojtyla (Belmont CA: Wadsworth/Thomson Learning, 2001).

Wojtyla, Karol, "Person, Subject and Community," in Person and Community: Selected Essays, trans. by Theresa Sandok, OSM (New York: Peter Lang, 1993).

"Subjectivity and the Irreducible in Man," in Analecta Husserliana, (1978).

, Love and Responsibility. trans. by H.T. Willets (San Francisco: Ignatius Press, 1993).

, Person and Community: Selected Essays, trans. by Theresa Sandok, OSM. (New York: Peter Lang, 1993).

The Acting Person. trans by Anna-Teresa Tymieniecka for publication in the Reidel Book Series Annalecta Husserliana. (Dordrecht, Holland; Boston, USA; London, England: D. Reidel Pub. Co., 1979). 


\section{HUMAN PERSON AND HUMAN DIGNITY}

Wook, Chang, "The Ultimate Foundation of Human Dignity in St. Thomas Aquinas," in Acta of the Fourth International Conference of the Asian Association of Catholic Philosophers. Humanity in the 21st Century: Towards A New Vision. Seoul (The Research Institute of Korea, CUK, 2000). 